Review Article

\title{
A Review of the Current Status of Japanese Encephalitis in Uttar Pradesh, India
}

\author{
$\underline{\text { Ramesh Chandra' }}^{1}, \underline{\text { NP Singh }}{ }^{2}, \underline{\text { RS Sharma }} 3 \underline{\text { S Kamal }}^{4}, \underline{\text { HK Aggrawal }}^{5}, \underline{\text { SN Sharma }}^{6}$ \\ ${ }^{1,4}$ Regional Office of Health \& Family Welfare (NVBDCP), Kendriya Bhawan, $9^{\text {th }}$ Floor, Aliganj, Lucknow, U.P., India. \\ ${ }^{2}$ Scientist Emeritus \& Ex-Prof. \& Head, Deptt of Zoology, University of Rajasthan, Jaipur, Rajasthan, India. \\ ${ }^{3}$ Advisor, WHO for VBD \& Ex-Addl. Director, NVBDCP, 22, Sham Nath Marg, Delhi, India. \\ ${ }^{5}$ State Programme Office for AES/JE, Govt. of U.P., Swasthya Bhawan, Lucknow, U.P., India. \\ ${ }^{6}$ National Centre for Disease Control, 22 Sham Nath Marg, Delhi, India. \\ DOI: https://doi.org/10.24321/0019.5138.202182
}

\section{I $\quad \mathbf{N} \quad \mathbf{F} \quad \mathbf{O}$}

\section{Corresponding Author:}

S Kamal, Regional Office of Health \& Family Welfare (NVBDCP), Kendriya Bhawan, $9^{\text {th }}$ Floor, Aliganj, Lucknow, U.P., India.

E-mail Id:

shaukatkamal25@yahoo.in

Orcid Id:

https://orcid.org/0000-0002-3358-1572

How to cite this article:

Chandra R, Singh NP, Sharma RS, Kamal S, Aggrawal HK, Sharma SN. A Review of the Current Status of Japanese Encephalitis in Uttar Pradesh, India. J Commun Dis. 2021;53(4):119-134.

Date of Submission: 2021-07-28

Date of Acceptance: 2021-12-01

\section{$\begin{array}{llllllll}\mathbf{A} & \mathbf{B} & \mathbf{S} & \mathbf{T} & \mathbf{R} & \mathbf{A} & \mathbf{C} & \mathbf{T}\end{array}$}

Japanese Encephalitis (JE) is an arboviral disease transmitted by mosquitoes. It is a disease of the poor and young (less than 15 years of age) in rural settings with maximum probabilities of their exposure to mosquitoes that are zoophilic. The disease pattern reflects a large proportion of subclinical cases to a small proportion with disease manifestations. It becomes fatal in U.P. in about $40 \%$ of the cases (due to seizures) in the absence of early treatment and leads to sequelae in one-third of the cases. Nearly half of the states of India are endemic for Japanese Encephalitis. Both the Govt of India and the State Govt have taken up the disease seriously and made all possible multi-sectoral approaches/ efforts to contain the menace of the disease. Rehabilitation centres have been established in the affected districts to provide physio and speech therapy. Even National Disaster Management Authority (NDMA) participated to generate awareness among the community against the dreadful disease. With all efforts, a plateau-like situation of the disease has been reached over the years. More coordinated efforts are required in tackling this problem. The environmental conditions will govern the spread of the virus along with the vector. The present article reflects an overview of the problem of JE and efforts made so far to tackle this disease and make the younger generation aware of their contribution through open field of the research in restricting the spread of the disease as well as complete cure of the seizures due to JE.

Keywords: Japanese Encephalitis (JE) Outbreak, Surveillance, Intervention Measures, Culex vishuni gp, Case Management, JE vaccination

\section{Background History}

Uttar Pradesh is one of the most densely populated states in India with nearly 199.81 million population (2011 census) dispersed in 75 revenue districts and 18 divisions. It contributes to $16.50 \%$ of the country population with a population density of 829 per square kilometre leading to the depravity of basic amenities and health facilities among the majority of them. The literacy rate is about $68 \%$, which is below the national average.

The eastern part of Uttar Pradesh (UP) has been endemic 
for Japanese Encephalitis (JE). The first epidemic of JE was reported from this area in 1978 and recurrent outbreaks have been reported from various districts of eastern UP since then. ${ }^{1-11,13-14}$ The disease affected all age groups in the beginning but it has been confined mainly to children below 15 years of age and is a major cause of acute childhood encephalopathy. Various factors may be involved in the transmission of the disease in this part of the state. Japanese Encephalitis (JE) disease is caused by an arbovirus, transmitted by mosquitoes. It is a disease of the poor and young (less than 15 years) in rural settings with maximum probabilities of their exposure to mosquitoes of zoophilic. The disease pattern reflects a large proportion of sub-clinical cases in contrast to a small proportion with disease manifestations. The disease becomes fatal in U.P. in about $40 \%$ of the cases (because of seizures) in the absence of early treatment and leads to sequelae in onethird of the cases.

Although various hospital and laboratory-based studies have been conducted on the epidemiology of JE in various parts of India including Uttar Pradesh, still the need for further research, to have a much clear understanding of the disease epidemiology, is beyond any question. Kumari \& Joshi ${ }^{11}$ had reviewed the epidemiology of JE in the country including Uttar Pradesh since 1978, and had suggested some recommendations for its prevention and control. In the review, it has been reflected that UP contributed onefifth of the disease burden $(20.4 \%$ in terms of morbidity and $18.7 \%$ in mortality) to the total JE burden of the country from 1978 to 1987 . The contribution increased to $24.3 \%$ in morbidity and $20.9 \%$ in mortality between 1988 and 1997 . The morbidity and mortality increased to half of the total JE problem of the country between 1998 and 2009. The proportion of JE cases reported from Uttar Pradesh in 1997 was only 14\%, which increased in 1998. The outbreak in UP in 2005 contributed over $90 \%$ of JE morbidity and $89 \%$ mortality in the country. The case definition of JE revised by the National Vector Borne Disease Control Programme (NVBDCP) in 2006 was followed for epidemiological surveillance for acute encephalitis syndrome (AES) which aimed to undertake JE surveillance and thereafter confirmation of JEV infection using IgM ELISA test. The present document accounts for various efforts made by the state of Uttar Pradesh in strengthening and effecting the diagnostic and treatment facilities, and preventive measures to reduce morbidity and mortality both, in prevailing circumstances of JE virus circulation in domestic and pet animals, in addition to ardeid birds. ${ }^{5}$

\section{Data Collection, Compilation, Analysis and Interpretation}

A multipronged approach was planned and implemented as the national strategy for the prevention and control of
Japanese Encephalitis (JE). It includes the following: Early diagnosis and complete case management; Integrated Vector Management and Vector Surveillance; Supervision, monitoring, surveillance and evaluation; Strengthening the capacity of human resource in health; Advocacy, communication and social mobilisation for behavioural impact and inter-sectoral convergence and Programme management. In order to ensure action on different approaches of the disease diagnosis and treatment, prevention and control, inter-sectoral convergence and social awareness with active participation, the Japanese Encephalitis (JE) endemic affected 35 districts were visited during different years. The activities related to different approaches were observed in the districts. The observation made so and data collected from the districts were compiled, analysed and then interpreted, and have been presented in the contribution.

\section{Salient Observations and Discussion}

Since there was no identified programme for the prevention and control of the Japanese Encephalitis (JE) disease, data regarding the number of JE cases reported by the state from various treatment hospitals including BRD Medical College, Gorakhpur from 1978, the year of the first epidemic of Japanese Encephalitis (JE) were collected and have been furnished through a graphic presentation in the document (Figure 1a). ${ }^{1-4,7-10,12-16}$ In the early years of occurrence of $\mathrm{JE}$, proportionately all age groups of the population were affected but during the end of the 1980s, youngsters aged up to 15 years were more affected by JE. The disease is not reported from all 75 districts of the state but the maximum number of JE reporting districts in the eastern half of the state remained only 40 during the last 42 years, though the number of affected districts never exceeded 20 in any single year till 2000 AD (Figure 1b). District Gorakhpur reported only two cases of JE during 1984 with no mortality. It is worth mentioning here that the maximum cases of JE are reported from Gorakhpur and Basti divisions, which were erstwhile only Gorakhpur division. Hence, the Gorakhpur area, comprising these two divisions and Bahraich and Lakhimpur Kheri districts, is the main contributor to the JE problem. Initially, the problem was not large but over time, Uttar Pradesh accounted for $70 \%$ of this national problem. The average case fatality rate (CFR) ranged between $48 \%$ in 1979 to $19.10 \%$ in 1998 (Figure $1 c$ ). However, the number of JE affected districts increased during 2005, when a large epidemic occurred involving 34 districts of eastern Uttar Pradesh with 5581 seizures and 1387 deaths, resulting in $25 \%$ case fatality rate (CFR), at the time when medical services have acquired much advanced facilities. The unprecedented occurrence of the disease in 1978 resulted in more than $50 \%$ mortality in district Lakhimpur Kheri [38 cases (C)/ 32 Deaths (D)], Pilibhit (28C/ 14D), Gonda (38C/ 18D), Raebareli (11C/ 09D) and Shahjahanpur (21C/ 
11D). This pattern was seen in district Basti (48C/ 32D), Azamgarh (14C/ 09D), and Ghazipur (16C/ 10D) in 1979; Lakhimpur Kheri (12C/07D) and Gonda (30C/ 15D) again in 1980; district Gorakhpur (12C/06D) and Deoria (11C/ 06D) in 1981; district Lucknow in 1982 (19C/ 11D); district Deoria (45C/ 23D) and Allahabad (17C/ 12D) in 1983; district Bahraich in 1989 (15C/ 07D); district Mau in 1993 (2C/2D); district Ambedkar Nagar in 1999 (2C/1D); district Hardoi in 2001 (2C/ 1D); district Balrampur in 2002 (3C/ 2D); district Saharanpur in 2003 (7C/ 4D) and 2004 (2C/ 1D), district Muzaffarnagar (20C/ 19D) and Jaunpur (2C/ 2D) in 2005. It is evident from Figure 1a that peaks of the encephalitis cases were observed in 1978, 1988, 1998-1999 and 20172018 (with less sharpness) but the cycle destined to occur in 2008, was possibly preponed in 2005 with all-time sharp peak of morbidity and mortality. The perusal and analysis of the data revealed that cases of JE start to occur from July every year and end with the end of the calendar year with peak in the month of September (Figure 3a), which coincides with the monsoon period in the state when there is abundant rainwater collection in paddy fields and ponds that provide congenial conditions for the development of JE vectors, Culex vishnui, Culex pseudovishnui, Culex tritaeniorhynchus, and Culex bitaeniorhynchus. ${ }^{6}$

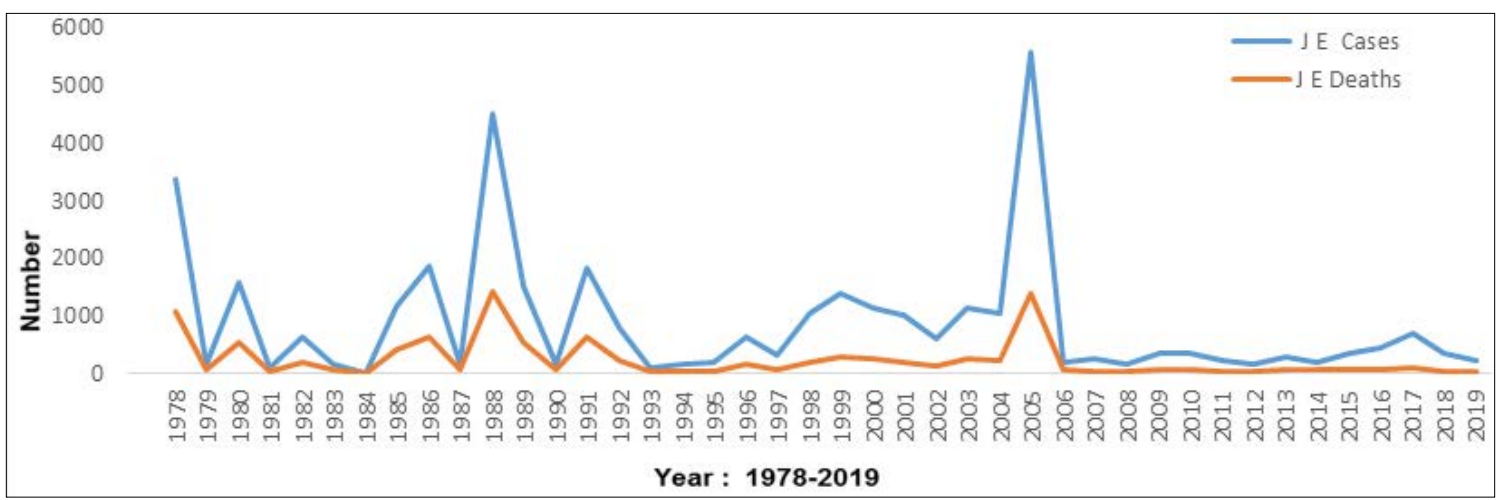

Figure I (a).Yearwise Cases and Deaths due to Japanese Encephalitis (JE) in Uttar Pradesh since 1978

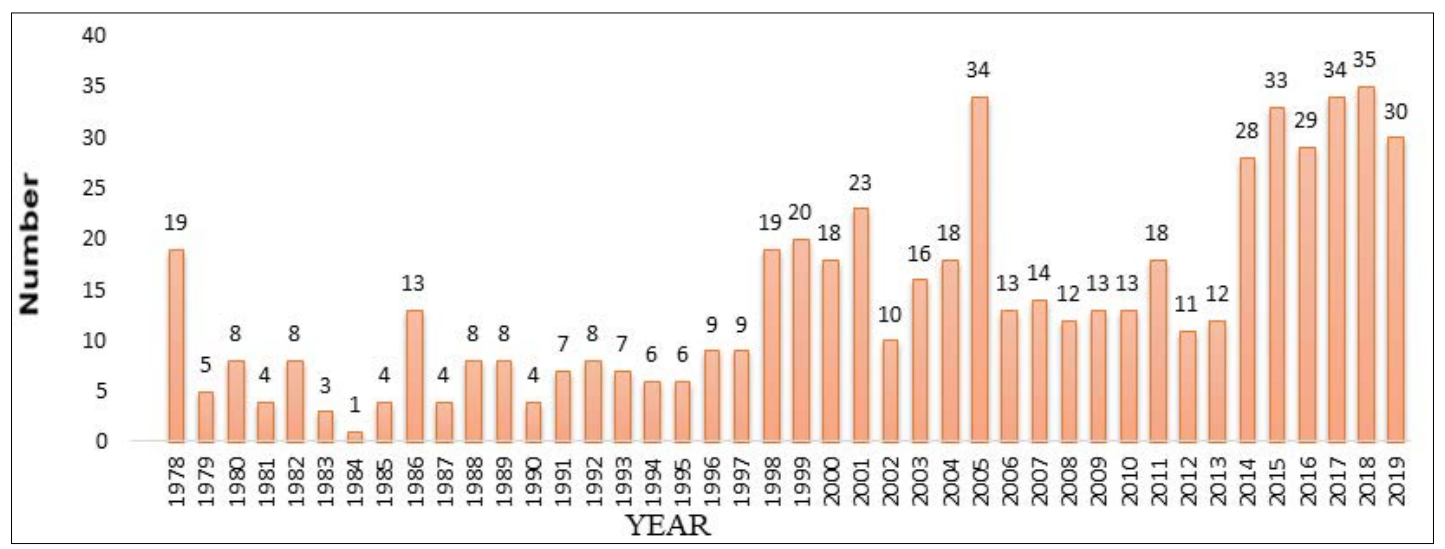

Figure I(b). Yearwise Distribution of the Number of Districts affected by Japanese Encephalitis (JE) in Uttar Pradesh since 1978

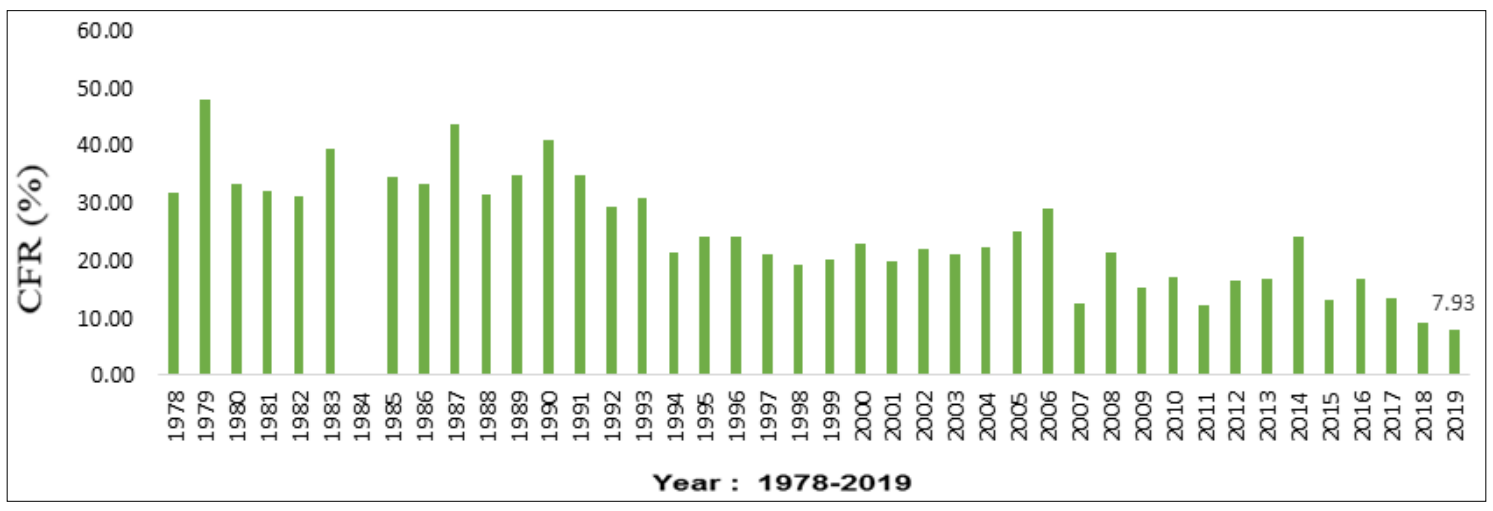

Figure I(c).Case Fatality Rate (CFR) due to JE in Uttar Pradesh (\%) since 1978 


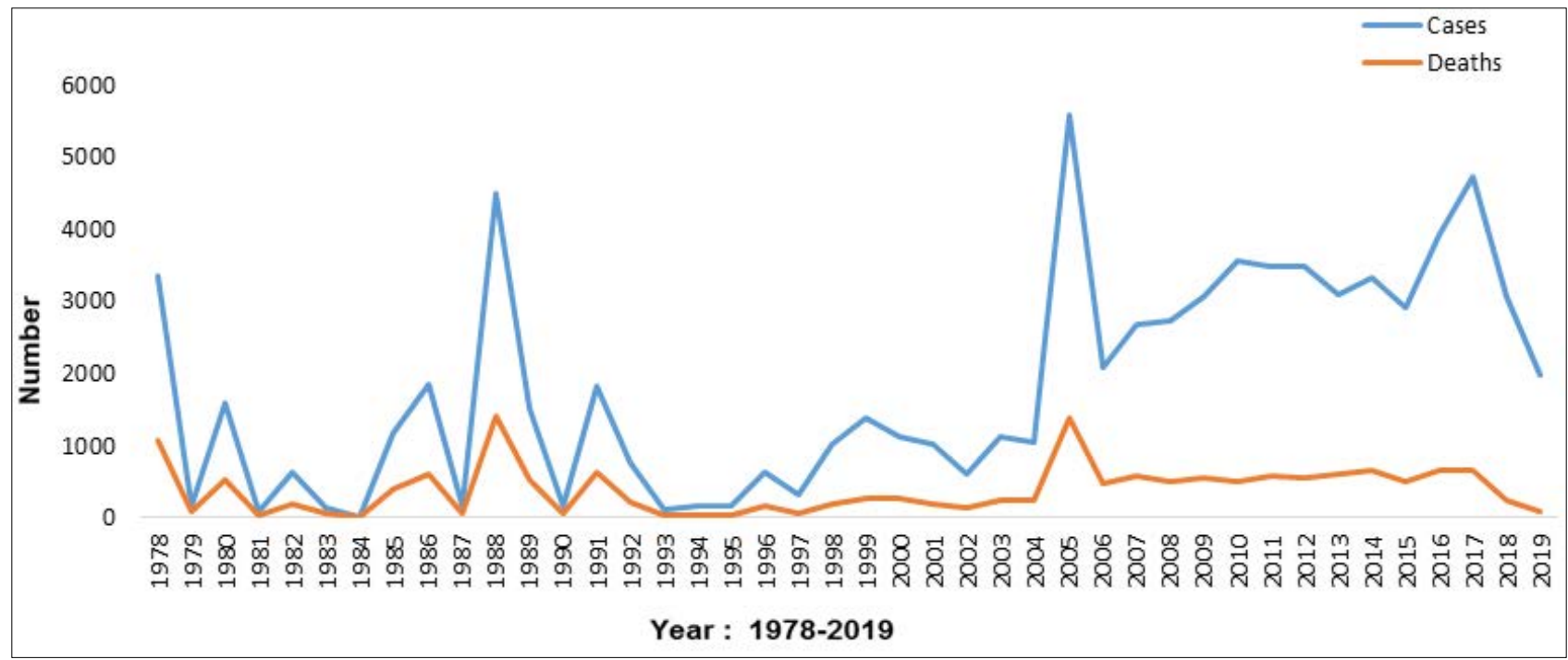

Figure 2(a).Yearwise Distribution of Cases and Deaths due to Acute Encephalitis Syndrome (AES) in Uttar Pradesh since 1978

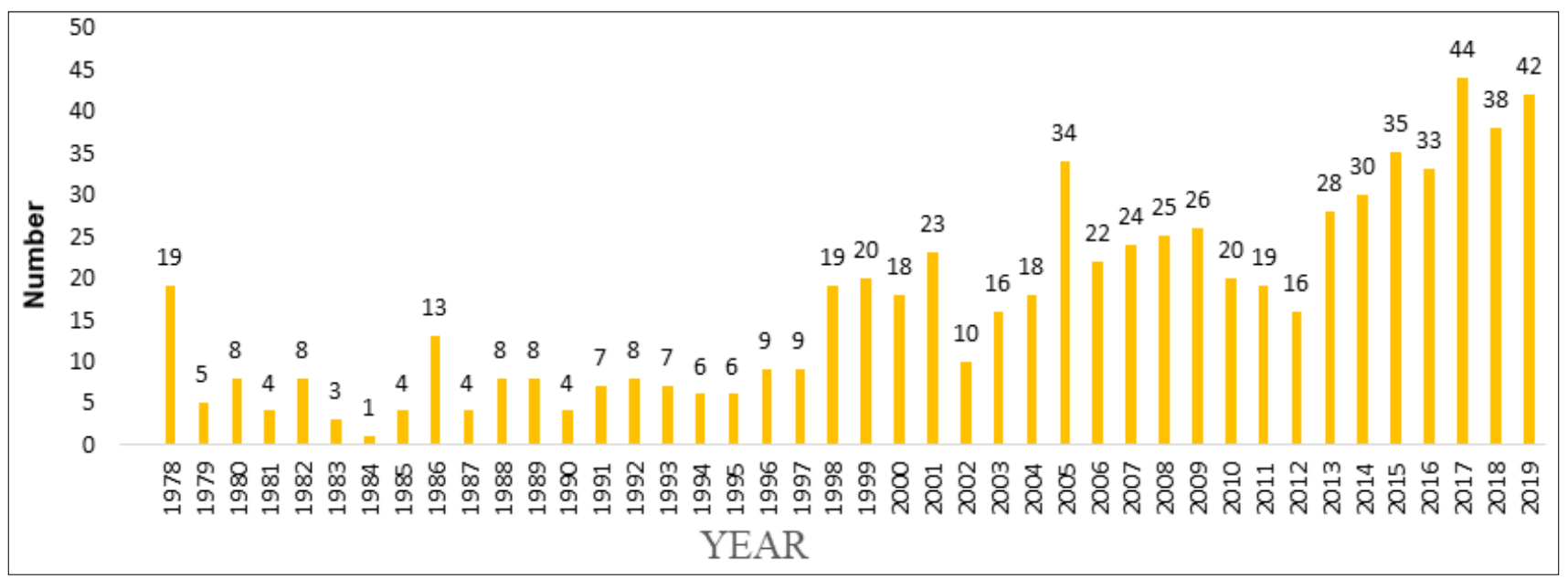

Figure 2(b). Yearwise Distribution of the Number of Districts affected by Acute Encephalitis Syndrome (AES) in Uttar Pradesh since 1978

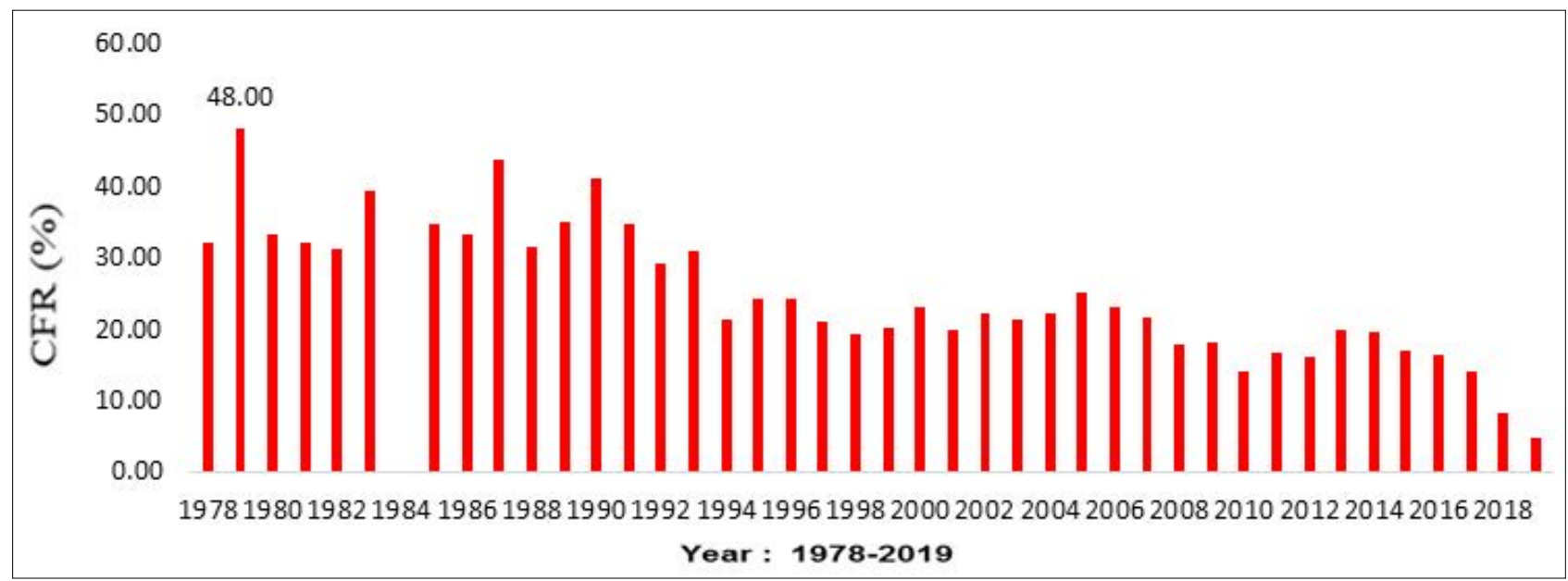

Figure 2(c).Case Fatality Rate (CFR) due to AES in Uttar Pradesh (\%) since 1978 


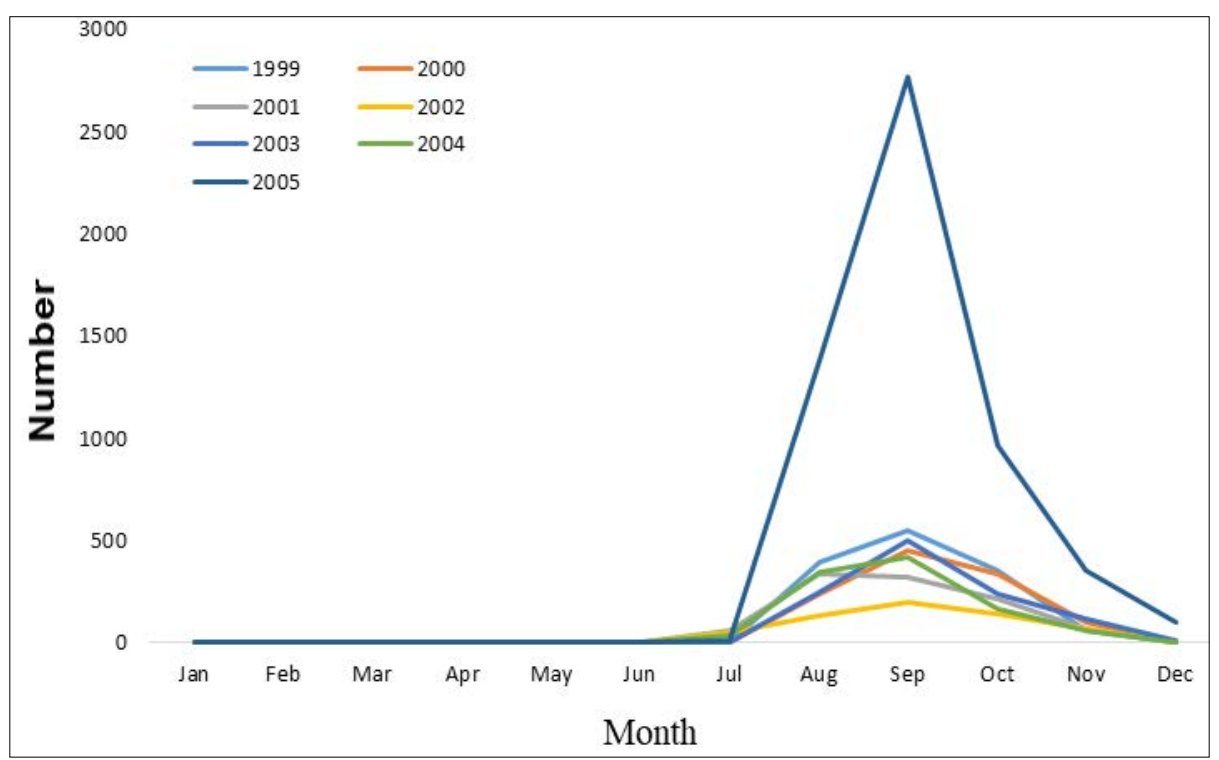

Figure 3(a).Monthwise Occurrence of JE cases from 1999-2005 in Uttar Pradesh

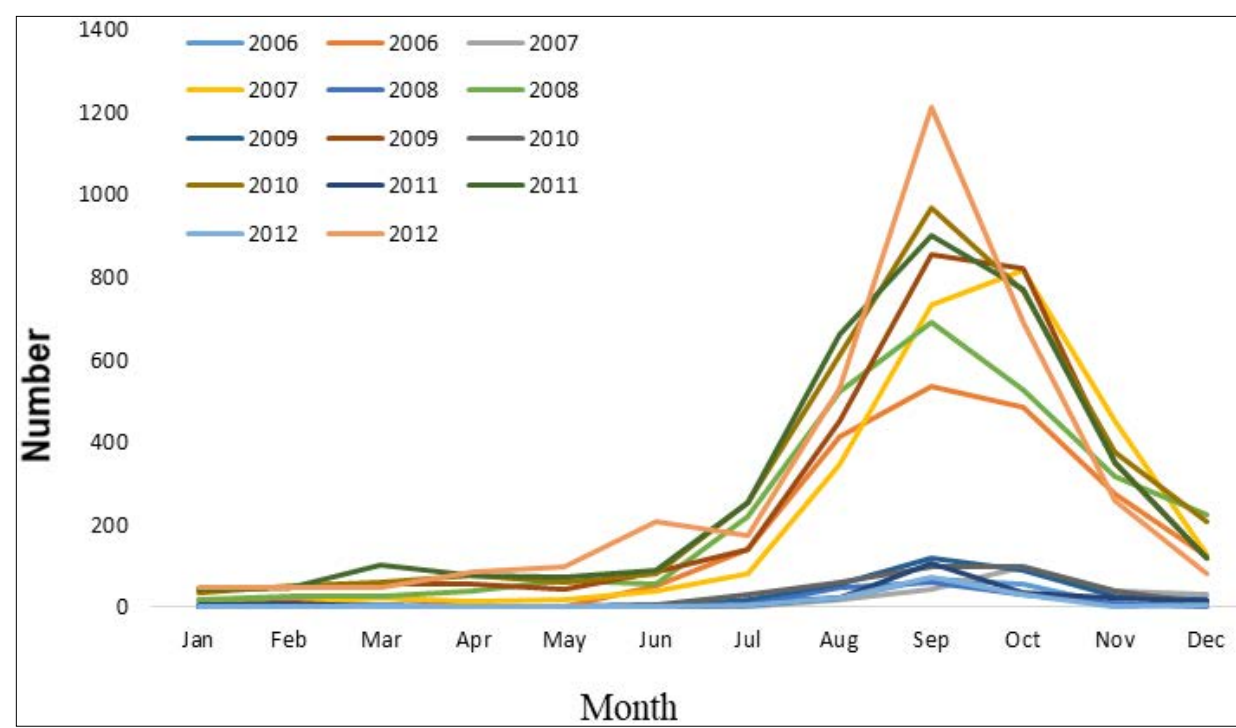

Figure 3(b).Monthwise Occurrence of AES cases from 2006-20 I 2 in Uttar Pradesh

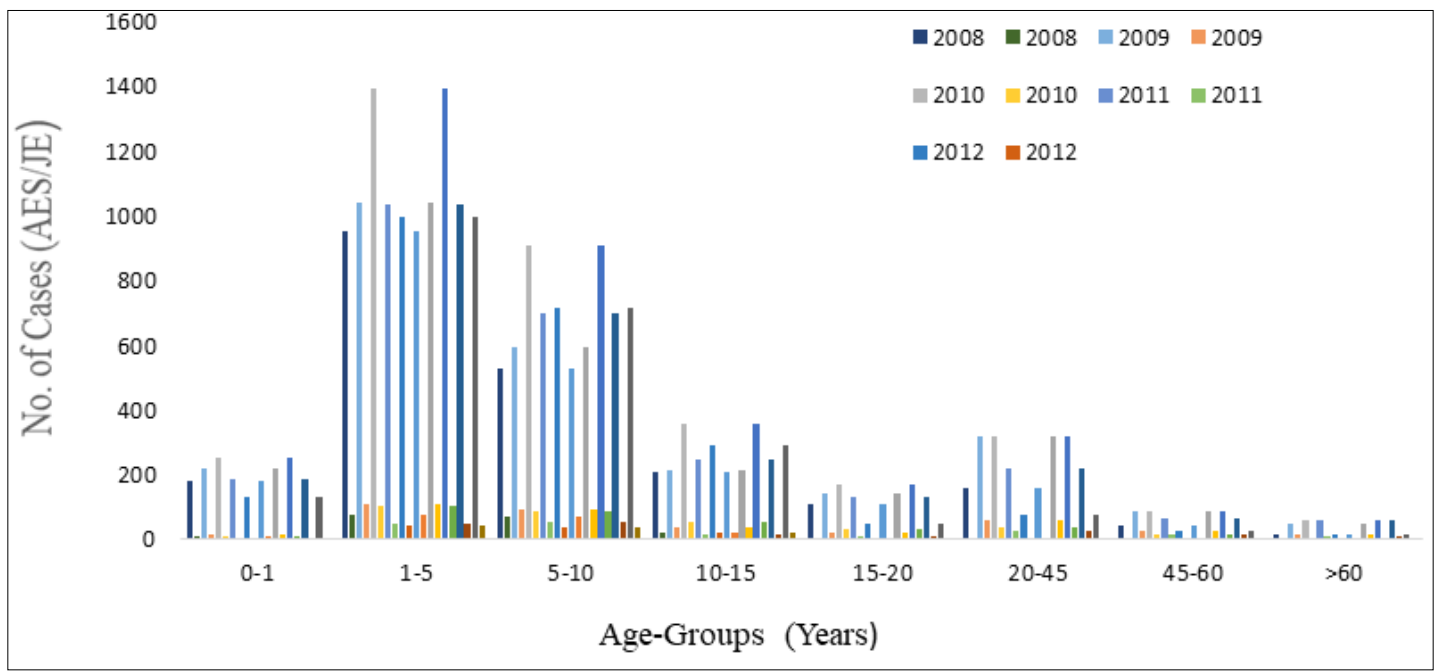

Figure 4.Occurrence of AES/ JE cases in Various Age Groups in Uttar Pradesh 


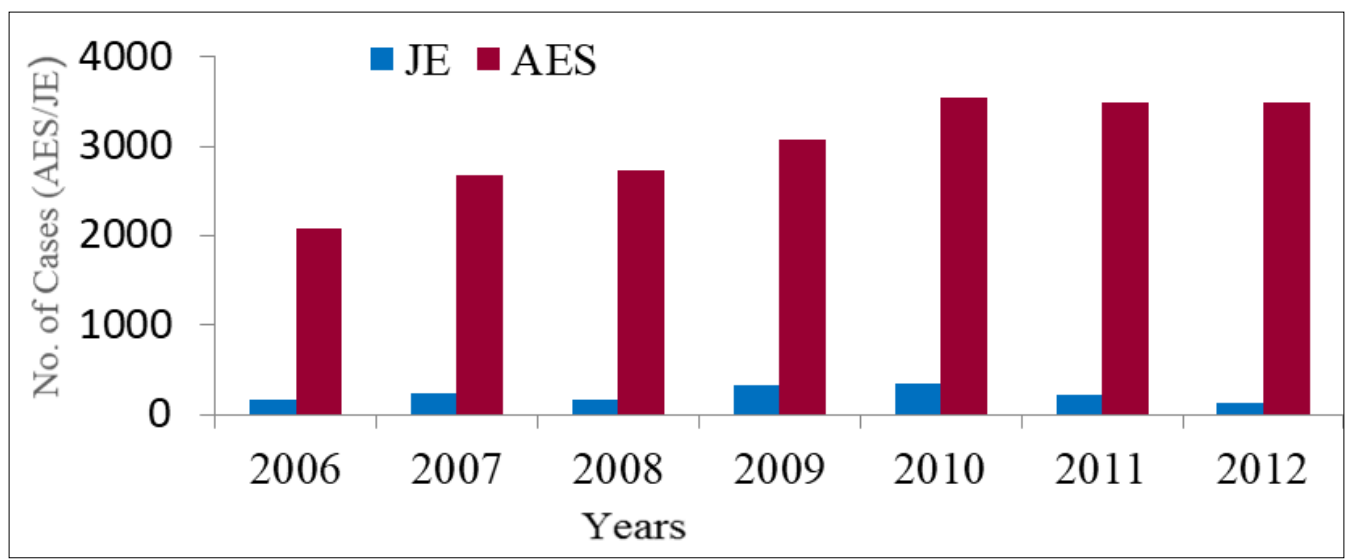

Figure 5.Prevalence of JE and AES after Institution of Intensified Diagnostic, Treatment, Preventive Intervention Measures through Inter-sectoral Coordination

Table I.Occurrence of AES/ JE Cases among Various Age Groups in Uttar Pradesh from 2008 to 2012

\begin{tabular}{|c|c|c|c|c|c|c|c|c|c|c|c|}
\hline \multirow{2}{*}{ S. No. } & \multirow{2}{*}{$\begin{array}{l}\text { Age Group } \\
\text { (Years) }\end{array}$} & \multicolumn{2}{|c|}{2008} & \multicolumn{2}{|c|}{2009} & \multicolumn{2}{|c|}{2010} & \multicolumn{2}{|c|}{2011} & \multicolumn{2}{|c|}{2012} \\
\hline & & AES & JE & AES & JE & AES & JE & AES & JE & AES & JE \\
\hline 1 & $0-1$ & 181 & 8 & 217 & 16 & 253 & 10 & 186 & 4 & 133 & 2 \\
\hline 2 & $1-5$ & 954 & 76 & 1041 & 109 & 1395 & 102 & 1038 & 50 & 997 & 41 \\
\hline 3 & $5-10$ & 526 & 72 & 592 & 93 & 908 & 87 & 700 & 54 & 714 & 38 \\
\hline 4 & $10-15$ & 208 & 20 & 214 & 35 & 360 & 55 & 246 & 16 & 294 & 21 \\
\hline 5 & $15-20$ & 111 & 0 & 141 & 20 & 168 & 33 & 130 & 10 & 46 & 4 \\
\hline 6 & $20-45$ & 157 & 0 & 321 & 58 & 317 & 38 & 220 & 27 & 76 & 7 \\
\hline 7 & $45-60$ & 44 & 0 & 87 & 28 & 88 & 14 & 66 & 16 & 25 & 7 \\
\hline 8 & $>60$ & 13 & 0 & 50 & 16 & 59 & 5 & 60 & 11 & 18 & 1 \\
\hline 9 & Total & 2194 & 176 & 2663 & 375 & 3548 & 344 & 2646 & 188 & 2303 & 121 \\
\hline \multicolumn{2}{|c|}{$\begin{array}{l}\text { Proportion of } 1-15 \text { years } \\
\text { age group to total cases }\end{array}$} & 76.93 & 95.45 & 69.35 & 63.20 & 75.05 & 70.93 & 74.98 & 63.83 & 87.06 & 82.64 \\
\hline
\end{tabular}

\section{Surveillance of Japanese Encephalitis (JE) Cases}

The initial surveillance of Japanese Encephalitis (JE) was hospital-based when the cases of JE that approached treatment facilities available in the districts accounted to the credit of the disease. Since the epicentre of the disease was Gorakhpur, the cases of JE belonging to the neighbouring districts including Bihar and Nepal, were mainly treated at BRD Medical College, Gorakhpur. The persons reporting for treatment with suspected symptoms of JE were subjected to serological or CSF or both examinations. The samples collected from the patients were sent to the National Institute of Virology (NIV), Pune or National Centre for Disease Control (NCDC), erstwhile National Institute of Communicable Diseases (NICD), Delhi for confirmation of JE as the state did not have any JE testing facility. The reports of the samples were received from the respective institutes (NCDC \& NIV) after a couple of weeks and based on the samples' positivity for JE, the persons related to the whole lot of samples were considered to be positive for JE and it was presumed that the persons resembling such JE suspect persons will be considered and accounted for JE. However, more samples were sent for confirmation of JE during the transmission period of the disease. The death audit of JE patients had to be carried out by the state on the instructions of higher authorities. While making the death audit of the persons or seizures of JE for undertaking preventive intervention measures, it was noticed that JE seizures or victims history did not coincide with the typical symptoms of JE and the districts raised this objection before the authorities of BRD Medical College, Gorakhpur through state higher authorities.

As per the prevailing strategy and available medical and diagnostic resources, approximately $50 \%$ of the sera samples of 5581 seizure cases in 2005 were subjected for confirmation of JE MAC-ELISA test and out of these samples, only 1042 persons (36.99\%) confirmed the presence of JE virus, which reflects that a major proportion of the cases are not due to JE but some other aetiological agents that 
are causing encephalopathy among the community. This interpretation may stand true to the preceding years' cases too. The definition derived for AES holds appropriate to ensure the treatment of the seizures with encephalopathy manifestations, which are not attributable to JE. Thus, the definition of AES and availability of diagnostic tools together with institution of preventive and control facilities has led to a considerable decrease in the JE seizures, as is evident from Figures $1(\mathrm{a})$ and 5 but has widened the gap between AES \& JE cases, as the number of AES cases has considerably increased and that of JE cases has declined (Figures 2(a) and 5). The observations also revealed that the seasonality of the occurrence of AES cases (Figures 3(a) and $3 \mathrm{~b}$ ) and the age groups affected (Table 1 and Figure 4) are similar to that of JE except for the occurrence of a few AES cases during the rest of the lean months of the year (January-June). Although the number of AES cases and the number of districts affected by it have increased (Figure 2(b)), but the mortality has come down to $>10 \%$ (4.72\%) in 2019 (Figure 2(c)) and is less than the mortality due to JE (7.93\%) during 2019 (Figure 1(c)). However, the proportion of JE to total AES has come down to $11.34 \%$. The decline in mortality of AES cases is a great achievement of the state, when the aetiology of $60 \%$ AES cases is yet to be determined (Table 2) and efforts are being made in this direction. This decline in mortality, in AES as well as JE cases, has been possible due to the efforts of the state in coordinating the activities of different departments related to reducing the possible causes of encephalopathy, strengthening the diagnostic and treatment facilities and timely implementation of preventive measures, which are accounted as:

Table 2.List of Aetiology found in AES Cases of Uttar Pradesh during 2019

\begin{tabular}{|c|c|c|}
\hline $\begin{array}{c}\text { S. } \\
\text { No. }\end{array}$ & List of Aetiology and related Data & $\begin{array}{c}\text { No. of } \\
\text { Cases }\end{array}$ \\
\hline 1. & Aetiology & \\
\hline \multirow{4}{*}{} & Japanese Encephalitis & 198 \\
\cline { 2 - 3 } & Scrub Typhus & 285 \\
\cline { 2 - 3 } & Dengue & 64 \\
\cline { 2 - 3 } & Chikungunya & 39 \\
\cline { 2 - 3 } & Measles & 3 \\
\cline { 2 - 3 } & Varicella Zoster Virus (VZV) & 2 \\
\cline { 2 - 3 } & Herpes Simplex Virus (HSV) & 1 \\
\cline { 2 - 3 } & Mumps & 1 \\
\cline { 2 - 3 } & Typhoid & 17 \\
\cline { 2 - 3 } & Leptospirosis & 1746 \\
\hline 2. & Multiple Causative Organism & \\
\cline { 2 - 3 } & Total AES Cases & \\
\hline
\end{tabular}

\begin{tabular}{|c|c|c|}
\hline 3. & Total known aetiology & 697 \\
\hline 4. & $\begin{array}{c}\text { Percentage of known aetiology in } \\
\text { total AES cases }\end{array}$ & 39.91 \\
\hline 5. & Cases of unknown aetiology & 1049 \\
\hline 6. & $\begin{array}{r}\text { Percentage of unknown aetiology in } \\
\text { total AES cases }\end{array}$ & 60.09 \\
\hline
\end{tabular}

\section{Laboratory Diagnosis of AES/ JE Cases}

In the early years of JE occurrence, the state lacked JE testing facilities. The persons reporting for treatment with suspected symptoms of JE were subjected to serological or CSF or both examinations. The samples collected from the patients were sent to the National Institute of Virology (NIV), Pune or National Centre for Disease Control (NCDC), erstwhile National Institute of Communicable Diseases (NICD), Delhi for confirmation of JE disease. A few weeks' time was required to receive the results from the respective laboratories. Now the state has strengthened its diagnostic facility by establishing JE sentinel laboratories (Table 3 ) in JE endemic district hospitals. This has enabled the state to take early decisions and actions towards the treatment line, which is of course symptomatic in both cases. On strengthening the diagnostic laboratories, 68\%, 73\%, $82.70 \%$, and $90.82 \%$ sera samples of AES persons were tested in 2006, 2007, 2008 and 2009, respectively, out of which only $8.19 \%, 8.79 \%, 6.15 \%$ and $10.67 \%$ reflected positivity for JE in respective years. The JE prevalence to total AES cases from 2006 to 2019 has been depicted in Figure 6, which remains around deca (around 10) figure. The JE Kits for performing tests are supplied by the National Vector Borne Disease Control Programme (NVBDCP), Delhi (Government of India) on the demand of the state.

Table 3.Updated List of JE Diagnostic Sentinel Laboratories in Uttar Pradesh

\begin{tabular}{|c|c|}
\hline $\begin{array}{c}\text { S. } \\
\text { No. }\end{array}$ & Name of the JE Sentinel Laboratory \\
\hline A. & Apex Laboratories \\
\hline 1. & Grade-1 Virology Laboratory, KGMU Lucknow \\
\hline 2. & Microbiology Laboratory, SGPGI, Lucknow \\
\hline 3. & $\begin{array}{r}\text { Field Unit of NIV Pune (now Regional Medical } \\
\text { Research Institute) located at BRD Medical } \\
\text { College, Gorakhpur }\end{array}$ \\
\hline B. & Regional Laboratory \\
\hline 1. & Regional Laboratory, Swasthya Bhawan, Lucknow \\
\hline C. & Sentinel Laboratories \\
\hline 1. & District Hospital, Balrampur \\
\hline 2. & District Hospital, Sitapur \\
\hline 3. & District Hospital, Lakhimpur Kheri \\
\hline
\end{tabular}




\begin{tabular}{|c|c|}
\hline 4. & District Hospital, Raebareli \\
\hline 5. & District Hospital, Basti \\
\hline 6. & District Hospital, Siddharthnagar \\
\hline 7. & District Hospital, Gorakhpur \\
\hline 8. & District Hospital, Deoria \\
\hline 9. & District Hospital, Mahrajganj \\
\hline 10. & District Hospital, Kushinagar \\
\hline 11. & District Hospital, Gonda \\
\hline 12. & District Hospital, Bahraich \\
\hline 13. & District Hospital, Faizabad \\
\hline 14. & District Hospital, Azamgarh \\
\hline 15. & District Hospital, Sant Kabirnagar \\
\hline 16. & District Hospital, Shravasti \\
\hline 17. & District Hospital, Hardoi \\
\hline 18. & District Hospital, Ballia \\
\hline 19. & District Hospital, Mau \\
\hline
\end{tabular}

\section{Treatment of AES/ JE Cases}

In the early years of Japanese Encephalitis (JE) epidemics from 1978, JE cases were treated in the district hospitals and BRD Medical College, Gorakhpur. The cases were mainly brought to BRD Medical College, Gorakhpur. Limited treatment resources in the medical college and influx of a large number of cases from adjoining districts, states (Bihar) and countries (Nepal), sometimes resulted in overloading of the bed occupancy and unavailability of medical care provider staff. Keeping in view the transmission season of JE disease, the district hospitals and Community Health Centres ( $\mathrm{CHCS}$ ) were strengthened for the availability of beds, medicines, and medical care staff. $\mathrm{CHCs}$ were to work as Special JE treatment centres and Primary Health Centres (PHCs) had to provide first aid facility to the JE patients until the end of the 2000AD and beginning of 2001. The state had established Encephalitis Treatment Centres (ETCS) in all the CHCs of AES/ JE affected districts. Paediatric Intensive Care Units (PICUs) and mini PICUs (Table 4) had been established and made functional with the availability of a working strength of ventilators in the hospitals/ $\mathrm{CHCs}$ of districts highly affected by AES/ JE in order to ensure early treatment of seizures at their doorstep.

Early diagnosis and prompt treatment have resulted in bringing down mortality in AES cases to $4.72 \%$ and in JE cases to $7.93 \%$, which is very less in comparison to the prevailing average mortality due to AES and is a matter of credit to the state. The districts have also been provided with rehabilitation centres for physically impaired children with sequelae after treatment of AES/ JE cases.

\section{Preventive Intervention Measures}

\section{Anti-vector Measures}

The occurrence of seizures with encephalopathy were all considered to be due to JE, which necessitated anti-vector measures and as such with the opinion of higher-level experts, two rounds of Indoor Residual Spray (IRS) with B.H.C.50\% wdp at an interval of 60 days each, outdoor space spray with Malathion Technical (5.0\%) and indoor space spray with pyrethrum $(0.1 \%)$ along with personal protective measures were recommended. As a result of programme experts recommendation, the whole population of the highly affected districts, Gorakhpur, Maharajganj, Deoria, and Kushinagar was sprayed with B.H.C.50\% wdp (active ingredient dose $0.2 \mathrm{~g} / \mathrm{metre}^{2}$ ) in two rounds of 60 days each, which required a large quantity of the insecticide and other finances for equipment used in spray and payment of wages. The districts were also provided with vehicle-mounted and portable thermal fogging machines for outdoor space spray and atomisers or motorised machines for indoor space spray. Other less affected districts were also provided resources for IRS and space spray but not for the whole district.

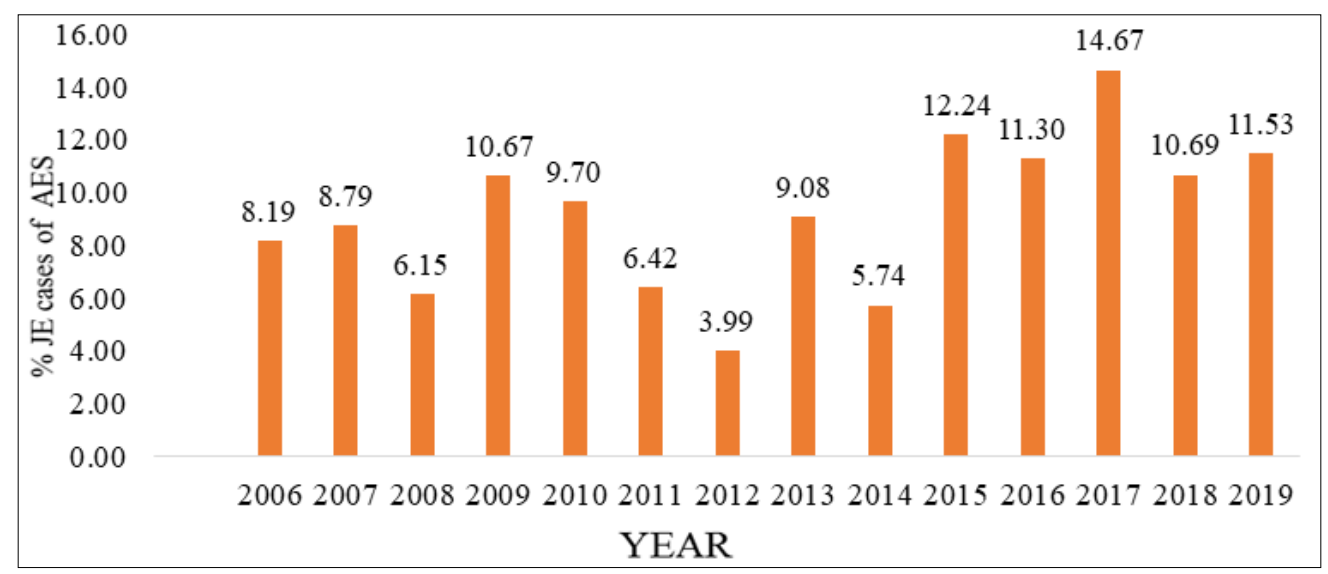

Figure 6.Proportion of JE Cases to AES Cases after Strengthening of Diagnostic Medical Care Facilities in Uttar Pradesh 
Table 4.Paediatric Intensive Care Units (PICUs)

Established/ Functional with Number of Ventilators in the Hospitals of AES/ JE Affected Districts

\begin{tabular}{|c|c|c|c|}
\hline $\begin{array}{l}\text { S. } \\
\text { No. }\end{array}$ & $\begin{array}{c}\text { Name of the District } \\
\text { Hospital with PICU }\end{array}$ & \multicolumn{2}{|c|}{$\begin{array}{c}\text { No. of Functional } \\
\text { Ventilators }\end{array}$} \\
\hline & & PICU & Mini PICU \\
\hline 1. & Gorakhpur & 17 & $\begin{array}{c}03 \text { in Chauri } \\
\text { Chaura, } \\
03 \text { in Piprauli, and } \\
03 \text { in Gagaha }\end{array}$ \\
\hline 2. & Mahrajganj & 15 & $\begin{array}{c}03 \text { in Nichlaul and } \\
03 \text { in Ratanpur }\end{array}$ \\
\hline 3. & Deoria & 15 & 03 in Rudrapur \\
\hline 4. & Kushinagar & 10 & $\begin{array}{c}03 \text { in Captainganj } \\
\text { and } \\
03 \text { in Hata }\end{array}$ \\
\hline 5. & Basti & 15 & $\begin{array}{c}03 \text { in Haraiya, } \\
03 \text { in Gaur, and } \\
03 \text { in Kudraha }\end{array}$ \\
\hline 6. & OPEC Hospital, Basti & 10 & 00 \\
\hline 7. & Sant Kabirnagar & 10 & $\begin{array}{c}03 \text { in Hainsar } \\
\text { Bazar and } 03 \text { in } \\
\text { Menhdawal }\end{array}$ \\
\hline 8. & Siddharthnagar & 15 & $\begin{array}{c}03 \text { in Dumariyaganj } \\
\text { and } \\
03 \text { in Bansi }\end{array}$ \\
\hline 9. & Bahraich & 10 & 00 \\
\hline 10. & Azamgarh & 5 & 00 \\
\hline 11. & Mau & 5 & 00 \\
\hline 12. & Gonda & 5 & 00 \\
\hline 13. & Hardoi & 5 & 00 \\
\hline 14. & Lakhimpur Kheri & 10 & 00 \\
\hline 15. & Raebareli & 5 & 00 \\
\hline \multirow[t]{2}{*}{16.} & Sitapur & 5 & 00 \\
\hline & Total & 157 & 45 \\
\hline
\end{tabular}

Keeping in view the exophilic and exophagic nature of the JE vector belonging to the Culex vishnui group, it was considered to stop the use of IRS against the JE vector and undertake only focal spray in and around 50 houses, from where JE cases had been reported. The action was executed in 1995 as is evident from Table 5. The focal spray was performed with Malathion 25\% wdp as the use of BHC $50 \%$ wdp was banned and provision for focal spray in the JE affected district was made accordingly. However, thrust was given for outdoor space spray (thermal fogging) with $5 \%$ solution Malathion Technical at fortnightly intervals during JE transmission season, for which 72 vehicle-mounted fogging machines were provided to the districts. After this, portable thermal fogging machines were arranged by the state and also supplied by NVBDC (erstwhile NAMP). The vector intervention measures are of utmost importance as the JE virus is found circulating in the environment reflecting $>10 \%$ JE seropositivity in the sera samples of 11 states collected from equines of 13 North Indian States. The stopping of IRS in the JE affected districts reflected no consequential adverse impact on the occurrence of the disease, thus saving huge resources to be utilised for other activities related to vector-borne diseases. Many districts have constructed fish hatcheries with the help of the fisheries department for the development of mosquito larvivorous fish, which are made available to the public for releasing them in water bodies in the vicinity of the human dwelling.

\section{JE Vaccination}

While preparing the action plan for prevention and control of JE in 1993, it was observed that children who are less than 15 years of age are more affected by JE. Thus, it was decided to saturate this age group by JE vaccination with inactivated mouse brain-derived vaccine manufactured by Central Research Institute (CRI), a prestigious institute of the Govt of India located at Kasauli (Himachal Pradesh), India. In a meeting of technical experts convened at Delhi on 19th April, 1993, it was decided to vaccinate the children of the age group of 5-10 years of districts highly affected by JE, Gorakhpur, Mahrajganj, and Deoria

Table 5.Population of JE added Districts of Gorakhpur Division Sprayed with BHC 50\% WDP in Two Rounds of 60 Days Each up to 1994 and thereafter with Malathion 25\% wdp

\begin{tabular}{|c|c|c|c|c|c|c|c|c|c|c|}
\hline \multirow{2}{*}{$\begin{array}{c}\text { S. } \\
\text { No. }\end{array}$} & \multirow{2}{*}{ District Sprayed } & \multicolumn{10}{|c|}{ Population (in million) Sprayed } \\
\cline { 3 - 12 } & $\mathbf{1 9 9 3}$ & $\mathbf{1 9 9 4}$ & $\mathbf{1 9 9 5}$ & $\mathbf{1 9 9 6}$ & $\mathbf{1 9 9 7}$ & $\mathbf{1 9 9 8}$ & $\mathbf{2 0 0 0}$ & $\mathbf{2 0 0 1}$ & $\mathbf{2 0 0 6}$ \\
\hline 1. & Gorakhpur & 2.30 & 2.30 & 0.30 & 0.30 & 0.30 & 0.31 & 0.10 & 0.10 & 0.15 \\
\hline 2. & Mahrajganj & 1.50 & 1.50 & 0.30 & 0.34 & 0.34 & 0.32 & 0.10 & 0.10 & 0.15 \\
\hline 3. & Deoria & 4.00 & 4.00 & 0.50 & 0.41 & 0.20 & 0.20 & 0.10 & 0.10 & 0.15 \\
\hline 4. & Kushinagar & $\begin{array}{c}\text { With } \\
\text { Deoria }\end{array}$ & $\begin{array}{c}\text { With } \\
\text { Deoria }\end{array}$ & $\begin{array}{c}\text { With } \\
\text { Deoria }\end{array}$ & $\begin{array}{c}\text { With } \\
\text { Deoria }\end{array}$ & 0.20 & 0.30 & 0.10 & 0.02 & 0.15 \\
\hline
\end{tabular}


(included district Kushinagar as it was undivided) keeping in view the availability of the vaccine in limited quantity. As per the schedule, the vaccine was to be administered to the children in two doses (each dose of $1.0 \mathrm{ml}$ ) at an interval of 7-14 days with a third booster dose after four weeks but within a year of the first dose. The vaccination was to be performed during inter-transmission period of $\mathrm{JE}$ and must be completed one month prior to the ensuing JE transmission period.

With the available quantity of the vaccine from CRI, Kasauli, the vaccination of children of the age group of 5-10 years was performed from 1993 to 1996 (Table 6). As is evident from Table 6, the available JE vaccine was quite inadequate in respect of the children belonging to 5-10 years of age group. Moreover, the vaccine was not provided timely to the state, as a result of which the vaccination performed was not expected to provide a positive epidemiological impact on the occurrence of JE cases. Though some children were protected from it despite being untimely vaccinated, others suffered from JE post-vaccination. CRI, Kasauli in later years could not supply the vaccine, as the vaccine was not manufactured and supplied due to administrative, technical and financial issues, and consequently, vaccination of the children with this vaccine came to an end.

After the occurrence of the JE epidemic during 2005, the Govt of India and the State Govt decided to vaccinate children of the age group of 1-15 years highly affected by JE, with live attenuated JE vaccine SA-14-14-2 manufactured in China with the supply and administration support of PATH. All 34 districts affected during 2005 were considered for undertaking vaccination of children of the age group of 1-15 years in a phased manner from 2006 to 2009. Administration of the vaccine subcutaneously with a single dose was ensured and overall $95.55 \%$ coverage was achieved (Table 7).

Later on, both the Govt of India and the State Govt together decided to vaccinate the children of age group of 1-15 years of the highly affected by JE districts of Gorakhpur and Basti division with the IInd dose of this vaccine, SA-14-14-2, and accordingly, the vaccination was effected during 2010 and overall $99.03 \%$ coverage was achieved (Table 8 ). The technical aspect regarding the impact of administering the IInd dose of vaccine in 2010 at varied time intervals from the Ist dose from 2006 to 2009 yet needs to be ascertained.

Table 6.JE Vaccination in Gorakhpur Division with Inactivated Mouse Brain-derived Vaccine

\begin{tabular}{|c|c|c|c|c|c|c|}
\hline \multirow{2}{*}{$\begin{array}{l}\text { S. } \\
\text { No. }\end{array}$} & \multirow{2}{*}{ District } & \multirow{2}{*}{ Year } & \multicolumn{4}{|c|}{ No. of Children who were administered Vaccine } \\
\hline & & & Ist Dose & IInd Dose & IIIrd Dose & Total \\
\hline \multirow{5}{*}{1.} & \multirow{4}{*}{ Gorakhpur } & 1993 & 17512 & 8245 & 0 & 25757 \\
\hline & & 1994 & 7016 & 6360 & 3914 & 17290 \\
\hline & & 1995 & 38293 & 29306 & 10493 & 78092 \\
\hline & & 1996 & 29139 & 23214 & 6223 & 58576 \\
\hline & Sub-Total (A) & & 91960 & 67125 & 20630 & 179715 \\
\hline \multirow{5}{*}{2.} & \multirow{4}{*}{$\begin{array}{l}\text { Deoria (with } \\
\text { Kushinagar) }\end{array}$} & 1993 & 183809 & 135623 & 9014 & 328446 \\
\hline & & 1994 & 271059 & 251023 & 195300 & 717382 \\
\hline & & 1995 & 7669 & 6842 & 6441 & 20952 \\
\hline & & 1996 & 22118 & 19829 & 17187 & 59134 \\
\hline & Sub-Total (B) & & 484655 & 413317 & 227942 & 1125914 \\
\hline \multirow{5}{*}{3.} & \multirow{4}{*}{ Mahrajganj } & 1993 & 77629 & 71259 & 35102 & 183990 \\
\hline & & 1994 & 28897 & 25479 & 18742 & 73118 \\
\hline & & 1995 & 40215 & 33012 & 25629 & 98856 \\
\hline & & 1996 & 30100 & 24570 & 11491 & 66161 \\
\hline & Sub-Total (C) & & 176841 & 154320 & 90964 & 422125 \\
\hline \multirow{4}{*}{4.} & \multirow{4}{*}{ Total } & 1993 & 278950 & 215127 & 44116 & 538193 \\
\hline & & 1994 & 306972 & 282862 & 217956 & 807790 \\
\hline & & 1995 & 86177 & 69160 & 42563 & 197900 \\
\hline & & 1996 & 81357 & 67613 & 34901 & 183871 \\
\hline & \multicolumn{2}{|c|}{ GRAND TOTAL (A + B + C) } & 753456 & 634762 & 339536 & 1727754 \\
\hline
\end{tabular}


Chandra $R$ et al.

Table 7.JE Vaccination in Gorakhpur Division with Live Attenuated JE Vaccine SA I4- I4-2

\begin{tabular}{|c|c|c|c|c|c|}
\hline S. No. & Districts & Year of Vaccination & $\begin{array}{c}\text { Targeted Children } \\
\text { (1-15 years) }\end{array}$ & $\begin{array}{c}\text { Total Vaccinated } \\
\text { Children }\end{array}$ & $\begin{array}{c}\text { Total Coverage } \\
(\%)\end{array}$ \\
\hline 1. & Lakhimpur Kheri & 2006 & 1183481 & 1218364 & 102.95 \\
\hline 2. & Deoria & 2006 & 1074219 & 1072683 & 99.86 \\
\hline 3. & Gorakhpur & 2006 & 1390307 & 1349047 & 97.03 \\
\hline 4. & Kushinagar & 2006 & 1095877 & 1085055 & 99.01 \\
\hline 5. & Maharajganj & 2006 & 778600 & 806996 & 103.65 \\
\hline 6. & Sant Kabir Nagar & 2006 & 542062 & 511417 & 94.35 \\
\hline \multirow[t]{2}{*}{7.} & Siddharthnagar & 2006 & 775934 & 792944 & 102.19 \\
\hline & Sub-Total & 2006 & 6840480 & 6836506 & 99.94 \\
\hline 8. & Ambedkarnagar & 2007 & 764068 & 741354 & 97.03 \\
\hline 9. & Bahraich & 2007 & 990327 & 992254 & 100.19 \\
\hline 10. & Balrampur & 2007 & 623020 & 622963 & 99.99 \\
\hline 11. & Barabanki & 2007 & 1074154 & 1063815 & 99.04 \\
\hline 12. & Basti & 2007 & 774322 & 750262 & 96.89 \\
\hline 13. & Gonda & 2007 & 1040501 & 1045957 & 100.52 \\
\hline 14. & Mau & 2007 & 719800 & 691341 & 96.05 \\
\hline 15. & Raebareli & 2007 & 1058987 & 1029154 & 97.18 \\
\hline 16. & Saharanpur & 2007 & 1056185 & 923246 & 87.41 \\
\hline 17. & Sitapur & 2007 & 1385606 & 1312326 & 94.71 \\
\hline \multirow[t]{2}{*}{18.} & Shravasti & 2007 & 331903 & 326485 & 98.37 \\
\hline & Sub-Total & 2007 & 9818873 & 9499157 & 96.74 \\
\hline 19. & Azamgarh & 2008 & 1400000 & 1402631 & 100.19 \\
\hline 20. & Ballia & 2008 & 1067337 & 1074655 & 100.69 \\
\hline 21. & Faizabad & 2008 & 649634 & 646847 & 99.57 \\
\hline 22. & Sultanpur & 2008 & 1234068 & 1230527 & 99.71 \\
\hline 23. & Lucknow & 2008 & 1506695 & 1479660 & 98.21 \\
\hline 24. & Hardoi & 2008 & 1270372 & 1297733 & 102.15 \\
\hline 25. & Unnao & 2008 & 1030843 & 1049428 & 101.80 \\
\hline 26. & Bareilly & 2008 & 1337392 & 1410208 & 105.44 \\
\hline \multirow[t]{2}{*}{27.} & Muzaffarnagar & 2008 & 1340236 & 1348320 & 100.60 \\
\hline & Sub-Total & 2008 & 10836577 & 10940009 & 100.95 \\
\hline 28. & Allahabad & 2009 & 1948804 & 1684826 & 86.45 \\
\hline 29. & Fatehpur & 2009 & 913749 & 680895 & 74.52 \\
\hline 30. & Pratapgarh & 2009 & 1028331 & 974161 & 94.73 \\
\hline 31. & Ghazipur & 2009 & 1202355 & 1007125 & 83.76 \\
\hline 32. & Jaunpur & 2009 & 1546931 & 1376128 & 88.96 \\
\hline 33. & Kanpur Nagar & 2009 & 1660500 & 1227209 & 73.91 \\
\hline \multirow[t]{3}{*}{34} & Shahjahanpur & 2009 & 953078 & 887219 & 93.09 \\
\hline & Sub-Total & 2009 & 9253748 & 7837563 & 84.70 \\
\hline & Grand Total & & 36749678 & 35113235 & 95.55 \\
\hline
\end{tabular}


Table 8.Special JE Vaccination Drive in Gorakhpur Division with Live Attenuated JE Vaccine SA 14-14-2

\begin{tabular}{|c|c|c|c|c|c|}
\hline S. No. & District & Year of Vaccination & $\begin{array}{c}\text { Targeted Children } \\
(\mathbf{1 - 1 5} \text { years) }\end{array}$ & $\begin{array}{c}\text { Total Vaccinated } \\
\text { Children }\end{array}$ & $\begin{array}{c}\text { Total Coverage } \\
\text { (\%) }\end{array}$ \\
\hline 1. & Basti & 2010 & 807199 & 800812 & 99.21 \\
\hline 2. & Deoria & 2010 & 1074533 & 1076237 & 100.16 \\
\hline 3. & Gorakhpur & 2010 & 1458276 & 1451883 & 99.56 \\
\hline 4. & Kushinagar & 2010 & 1170549 & 1158539 & 98.97 \\
\hline 5. & Maharajganj & 2010 & 901624 & 878546 & 97.44 \\
\hline 6. & Sant Kabir Nagar & 2010 & 549482 & 529304 & 96.33 \\
\hline 7. & Siddharthnagar & 2010 & 829157 & 829411 & 100.03 \\
\hline & Sub-Total & $\mathbf{2 0 1 0}$ & $\mathbf{6 7 9 0 8 2 0}$ & $\mathbf{6 7 2 4 7 3 2}$ & $\mathbf{9 9 . 0 3}$ \\
\hline
\end{tabular}

For protection from JE, the children less than 1 year of age were not vaccinated from JE vaccination since they were under maternal care, and later on, when they were between 1 and 2 years of age, they were covered for vaccination under routine universal immunization programme (UIP). Under this set-up, two doses of vaccine are being administered to children on fixed immunization days, Ist dose of vaccine at the age of 9 months and IInd dose between the age of 16 and 24 months from April 2013 vide Ministry of Health \& Family Welfare (Govt of India), Nirman Bhawan, New Delhi letter No. dated 26th March, 2013.

\section{Social Mobilization of Community}

In order to ensure public support in the execution of various activities, treatment, prevention and control of not only JE but AES too, various practices like inter-personal communication of health workers with community, drum beating, loudspeaker, posters, hoardings, handbills, and newspaper insertions were exercised with available limited resources in order to change and ensure the treatmentseeking behaviour of the public for their sufferings at the earliest and the nearest treatment centres/ hospitals to prevent mortality or sequelae due to AES/ JE.

National Disaster Management Authority (NDMA) took a serious note of the lack of awareness and participation of the community in reporting to nearby treatment centres for their suffering due to JE. The need of other public related departments like education, rural development, and panchayat raj institutions was felt important in addition to the medical and health department and as such NDMA with the support of state developed health education material (booklets, handbills, posters etc.). NDMA with the support of the Government of India and state government organised training of trainers (ToT) at the district level related to medical and health, education, rural development, panchayat raj institutions, civil defence etc
(Table 9), who in turn, trained the community at village level for mobilisation in order to ensure the earliest treatment at the nearest treatment centres/ hospitals to prevent mortality or sequelae due to AES/ JE, along with maintaining personal hygiene by ensuring proper hand wash prior to feeding and after defecation, only using deep bore water for drinking and stopping the use of shallow water hand pumps, keeping proper sanitation and not allowing stagnation of undue water collection in and around their dwellings, practising personal protective measures and using mosquito nets at the time of sleep to prevent mosquito bites.

Hon'ble Chief Minister of Uttar Pradesh is much devoted to the above acts through the dream project drive 'DASTAK' carried out 2-3 times in a year for a fortnight or complete month in inter-transmission period. All the public representatives (MPs, MLAs and other local leaders) are expected to ensure participation in such drives in their own areas. This social mobilisation, collectively with other efforts, has paid a dividend in bringing down the mortality of AES as well as JE (<10\%).

\section{Intersectoral Co-ordination}

As discussed above, the personnel of other departments, education, rural development, panchayat raj institutions (PRI) and civil defence were involved in social mobilisation of the community. The fisheries department was involved in the development of rearing of mosquito larvivorous fish (Gambusia affinis or other indigenous fish) to prevent the breeding of JE vector mosquitoes.

The rural development and panchayat raj department supported in ensuring the availability of safe drinking water and construction of latrines to prevent open defecation, which consequently prevents the spread of infection. The work done by these departments has been furnished in Tables 10 and 11. 
Table 9.Training of Trainers for Social Mobilisation/ Awareness among Community against AES/ JE with the Support of NDMA, NVBDCP (Govt of India and State Government) Conducted during 20 I I- I 3

\begin{tabular}{|c|c|c|c|c|c|c|}
\hline \multirow{2}{*}{ S. No } & \multirow{2}{*}{ Name of District } & \multicolumn{4}{|c|}{ No. of Participants } & \multirow{2}{*}{ Remarks } \\
\hline & & Medical & Paramedical & Other Departments & Total & \\
\hline 1. & Gorakhpur & 95 & 33 & 291 & 419 & Nov. 2011 \\
\hline 2. & Mahrajganj & 90 & 135 & 118 & 343 & May, 2012 \\
\hline 3. & Deoria & 87 & 146 & 124 & 357 & May, 2012 \\
\hline 4. & Kushinagar & 70 & 140 & 129 & 339 & May, 2012 \\
\hline 5. & Basti & 52 & 19 & 352 & 423 & May, 2012 \\
\hline 6. & Sant Kabir Nagar & 69 & 53 & 93 & 215 & May, 2012 \\
\hline 7. & Siddharthnagar & 21 & 21 & 138 & 180 & May, 2012 \\
\hline 8. & Bahraich & 80 & 146 & 145 & 371 & May, 2012 \\
\hline 9. & Shravasti & 75 & 163 & 148 & 386 & May, 2012 \\
\hline 10. & Gonda & 70 & 155 & 139 & 364 & May, 2012 \\
\hline 11. & Balrampur & 45 & 80 & 96 & 221 & May, 2012 \\
\hline 12. & Azamgarh & 9 & 112 & 368 & 489 & May, 2012 \\
\hline 13. & Ballia & 63 & 150 & 120 & 333 & May, 2012 \\
\hline 14. & Mau & 47 & 130 & 159 & 336 & May, 2012 \\
\hline 15. & Lakhimpur Kheri & 85 & 155 & 162 & 402 & June, 2012 \\
\hline 16. & Raebareli & 96 & 161 & 138 & 395 & March, 2013 \\
\hline 17. & Sitapur & 28 & 60 & 89 & 177 & March, 2013 \\
\hline 18. & Hardoi & 30 & 43 & 37 & 110 & March, 2013 \\
\hline 19. & Kanpur Dehat & 18 & 43 & 40 & 101 & March, 2013 \\
\hline 20. & Saharanpur & 39 & 80 & 186 & 305 & March, 2013 \\
\hline 21. & Muzaffarnagar & 43 & 78 & 82 & 203 & March, 2013 \\
\hline \multirow[t]{2}{*}{22.} & Barabanki & 32 & 86 & 87 & 205 & March, 2013 \\
\hline & Total & & & & 6674 & \\
\hline
\end{tabular}

Table I0.India Mark II Hand Pumps installed in AES/ JE affected Districts by Jal Nigam

\begin{tabular}{|c|c|c|c|c|}
\hline $\begin{array}{c}\text { S. } \\
\text { No. }\end{array}$ & Name of District & $\begin{array}{c}\text { No. of places provided for } \\
\text { India Mark II pump installation }\end{array}$ & $\begin{array}{c}\text { No. of places installed } \\
\text { with India Mark II pump }\end{array}$ & $\begin{array}{c}\text { No. of places left for } \\
\text { installation of India Mark II } \\
\text { pump }\end{array}$ \\
\hline 1. & Gorakhpur & 593 & 593 & 0 \\
\hline 2. & Mahrajganj & 271 & 271 & 0 \\
\hline 3. & Deoria & 341 & 341 & 0 \\
\hline 4. & Kushinagar & 720 & 720 & 0 \\
\hline 5. & Basti & 109 & 109 & 0 \\
\hline 6. & Sant Kabirnagar & 276 & 276 & 0 \\
\hline 7. & Siddharthnagar & 110 & 110 & 0 \\
\hline 8. & Azamgarh & 108 & 108 & 0 \\
\hline 9. & Mau & 174 & 174 & 0 \\
\hline 10. & Ballia & 175 & 175 & 0 \\
\hline 11. & Gonda & 84 & 84 & 0 \\
\hline
\end{tabular}




\begin{tabular}{|c|c|c|c|c|}
\hline 12. & Balrampur & 138 & 138 & 0 \\
\hline 13. & Bahraich & 173 & 173 & 0 \\
\hline 14. & Shravasti & 69 & 69 & 0 \\
\hline & Total & $\mathbf{3 3 4 1}$ & $\mathbf{3 3 4 1}$ & $\mathbf{0}$ \\
\hline
\end{tabular}

\section{Summary and Conclusion}

An in-depth review of the situation of Japanese Encephalitis (JE) disease in Uttar Pradesh revealed that the disease is prevalent in the state since 1978, cases of which occur every year from July onwards coinciding with the monsoon period in the state, when the increase in water bodies provide congenial conditions for JE vectors. The epidemics have been observed at an interval of 10 years but the epidemic that occurred in 2005 was preponed (the estimated time was 2008). Until this time, all the cases with encephalopathy were treated due to JE on the basis of the test results of representative sera samples of patients positive for JE in some samples only but after the epidemic of 2005, clinical features and laboratory diagnosis of sera samples of $50 \%$ cases reflected only $37 \%$ positivity for JE. JE surveillance, therefore, aims to identify patients with AES and thereafter confirm JEV infection using IgM ELISA test. The state has fared well in the direction of strengthening the diagnostic and treatment facilities at the patient doorstep, establishment of PICUs and mini PICUs with functional ventilator facility up to $\mathrm{CHC}$ level in JE affected districts, ensuring JE vaccination of children of 1-15 years age group with single-dose JE vaccine SA-14-14-2, manufactured in China and IInd dose administered in 7 highly JE affected districts of Gorakhpur and Basti division after ample time lag. The JE vaccination of children of 1-2 years age group has been incorporated in the UIP programme. The anti-vector intervention measures are being conducted effectively and support from other departments is also being received. The collective efforts of all these departments have resulted in the reduction of $100 \%$ JE cases of AES till 2005 (lab. confirmed 36.99\%) to $11.53 \%$ in 2019 (Figure 6) and subsequent reduction in mortality due to JE from $31.82 \%$ in 1978 and $48 \%$ in 1979 to $7.93 \%$ in 2019 , which is a matter of credit to the state. Though the number of AES seizures and the number of affected districts have increased yet the mortality due to AES seizures has been brought down to $4.72 \%$ by performing aforesaid activities.

Table I I. Construction of Latrines/ Toilets in AES/ JE affected Districts by Panchayat Raj Department under Total Sanitation Programme

\begin{tabular}{|c|c|c|c|c|c|c|c|c|c|c|}
\hline \multirow[b]{3}{*}{$\begin{array}{l}\text { S. } \\
\text { No. }\end{array}$} & \multirow[b]{3}{*}{$\begin{array}{c}\text { Name of } \\
\text { District }\end{array}$} & \multicolumn{9}{|c|}{ Individual House Hold Latrines (IHHL) } \\
\hline & & \multicolumn{3}{|c|}{ BPL Families (A) } & \multicolumn{3}{|c|}{ APL Families (B) } & \multicolumn{3}{|c|}{ Total Families $(A+B)$} \\
\hline & & 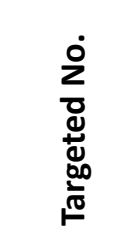 & 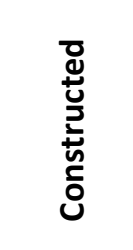 & 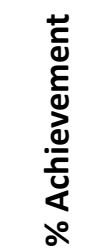 & 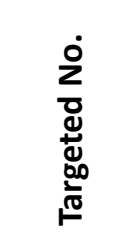 & 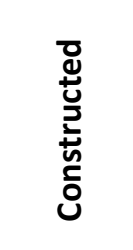 & 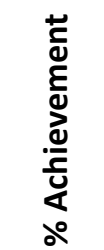 & 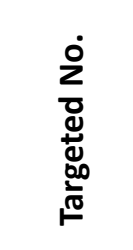 & 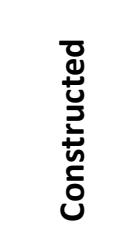 & 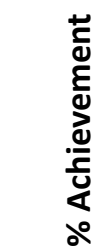 \\
\hline 1. & Gorakhpur & 211033 & 210993 & 99.98 & 280101 & 202339 & 72.24 & 491134 & 413332 & 84.16 \\
\hline 2. & Mahrajganj & 145090 & 144753 & 99.77 & 111256 & 90142 & 81.02 & 256346 & 234895 & 91.63 \\
\hline 3. & Deoria & 181225 & 171213 & 94.48 & 198893 & 165696 & 83.31 & 380118 & 336909 & 88.63 \\
\hline 4. & Kushinagar & 287089 & 234042 & 81.52 & 160033 & 145406 & 90.86 & 447122 & 379448 & 84.86 \\
\hline 5. & Basti & 160480 & 128134 & 79.84 & 120653 & 82793 & 68.62 & 281133 & 210927 & 75.03 \\
\hline 6. & $\begin{array}{c}\text { Sant } \\
\text { Kabirnagar }\end{array}$ & 121112 & 90642 & 74.84 & 227284 & 104716 & 46.07 & 348396 & 195358 & 56.07 \\
\hline 7. & Siddharthnagar & 139597 & 123643 & 88.57 & 133650 & 111651 & 83.54 & 273247 & 235294 & 86.11 \\
\hline 8. & Azamgarh & 186141 & 158907 & 85.37 & 466925 & 245710 & 52.62 & 653066 & 404616 & 61.96 \\
\hline 9. & Mau & 133766 & 108377 & 81.02 & 73752 & 57985 & 78.62 & 207518 & 166362 & 80.17 \\
\hline 10. & Ballia & 172179 & 167490 & 97.28 & 138937 & 124522 & 89.62 & 311116 & 292012 & 93.86 \\
\hline 11. & Gonda & 138500 & 117865 & 85.10 & 198080 & 140587 & 70.97 & 336580 & 258452 & 76.79 \\
\hline 12. & Balrampur & 65273 & 63529 & 97.33 & 136410 & 84121 & 61.67 & 201683 & 147650 & 73.21 \\
\hline
\end{tabular}


Chandra $R$ et al.

\begin{tabular}{|c|c|c|c|c|c|c|c|c|c|c|}
\hline 13. & Bahraich & 284073 & 226430 & 79.71 & 174857 & 165679 & 94.75 & 458930 & 392109 & 85.44 \\
\hline 14. & Shravasti & 104902 & 97449 & 92.90 & 54772 & 41761 & 76.25 & 159674 & 139210 & 87.18 \\
\hline 15. & Raebareli & 190306 & 190430 & 100.07 & 135862 & 124312 & 91.50 & 326168 & 314742 & 96.50 \\
\hline 16. & Sitapur & 305299 & 273463 & 89.57 & 255574 & 185138 & 72.44 & 560873 & 458601 & 81.77 \\
\hline 17. & $\begin{array}{c}\text { Lakhimpur } \\
\text { Kheri }\end{array}$ & 73000 & 93314 & 127.83 & 124463 & 124463 & 100.00 & 197463 & 217777 & 110.29 \\
\hline 18. & Hardoi & 199989 & 199989 & 100.00 & 231215 & 211279 & 91.38 & 431204 & 411268 & 95.38 \\
\hline 19. & Kanpur Dehat & 126650 & 121150 & 95.66 & 117436 & 86598 & 73.74 & 244086 & 207748 & 85.11 \\
\hline 20. & Saharanpur & 49458 & 49458 & 100.00 & 192771 & 184011 & 95.46 & 242229 & 233469 & 96.38 \\
\hline & TOTAL & $\mathbf{3 2 7 5 1 6 2}$ & $\mathbf{2 9 7 1 2 7 1}$ & $\mathbf{9 0 . 7 2}$ & $\mathbf{3 5 3 2 9 2 4}$ & $\mathbf{2 6 7 8 9 0 9}$ & $\mathbf{7 5 . 8 3}$ & $\mathbf{6 8 0 8 0 8 6}$ & $\mathbf{5 6 5 0 1 7 9}$ & $\mathbf{8 2 . 9 9}$ \\
\hline
\end{tabular}

\begin{tabular}{|c|c|c|c|c|c|c|c|c|c|c|}
\hline \multirow[b]{2}{*}{$\begin{array}{l}\text { S. } \\
\text { No. }\end{array}$} & \multirow[b]{2}{*}{ Name of District } & \multicolumn{3}{|c|}{$\begin{array}{l}\text { Sanitary Complex for } \\
\text { Women (SCW) }\end{array}$} & \multicolumn{3}{|c|}{ School Toilets } & \multicolumn{3}{|c|}{ Anganwadi Toilets } \\
\hline & & 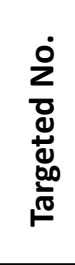 & 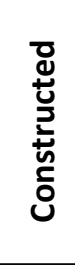 & 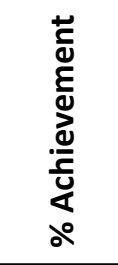 & 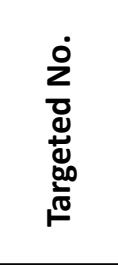 & 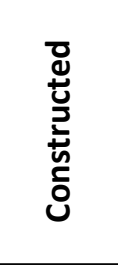 & 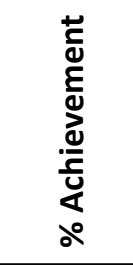 & 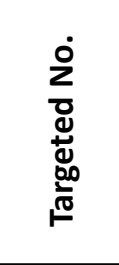 & 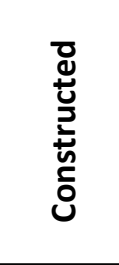 & 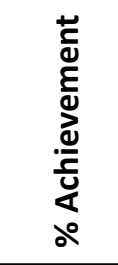 \\
\hline 1. & Gorakhpur & 121 & 121 & 100.00 & 6036 & 6036 & 100.00 & 1823 & 1823 & 100.00 \\
\hline 2. & Mahrajganj & 55 & 55 & 100.00 & 2956 & 2956 & 100.00 & 1461 & 1461 & 100.00 \\
\hline 3. & Deoria & 39 & 31 & 79.49 & 4696 & 4696 & 100.00 & 1461 & 1461 & 100.00 \\
\hline 4. & Kushinagar & 25 & 25 & 100.00 & 5120 & 5120 & 100.00 & 2133 & 2133 & 100.00 \\
\hline 5. & Basti & 40 & 26 & 65.00 & 3695 & 3695 & 100.00 & 2223 & 2223 & 100.00 \\
\hline 6. & Sant Kabirnagar & 35 & 35 & 100.00 & 2368 & 2368 & 100.00 & 991 & 991 & 100.00 \\
\hline 7. & Siddharthnagar & 50 & 50 & 100.00 & 4128 & 4128 & 100.00 & 1481 & 1481 & 100.00 \\
\hline 8. & Azamgarh & 87 & 87 & 100.00 & 4888 & 4888 & 100.00 & 4101 & 4101 & 100.00 \\
\hline 9. & Mau & 13 & 13 & 100.00 & 2494 & 2494 & 100.00 & 1090 & 1090 & 100.00 \\
\hline 10. & Ballia & 115 & 120 & 104.35 & 4636 & 4636 & 100.00 & 1888 & 1888 & 100.00 \\
\hline 11. & Gonda & 16 & 16 & 100.00 & 4298 & 4298 & 100.00 & 2031 & 2031 & 100.00 \\
\hline 12. & Balrampur & 18 & 18 & 100.00 & 2948 & 2948 & 100.00 & 1215 & 1215 & 100.00 \\
\hline 13. & Bahraich & 10 & 10 & 100.00 & 6100 & 6100 & 100.00 & 1802 & 1802 & 100.00 \\
\hline 14. & Shravasti & 10 & 10 & 100.00 & 1838 & 1838 & 100.00 & 650 & 650 & 100.00 \\
\hline 15. & Raebareli & 25 & 25 & 100.00 & 5809 & 5809 & 100.00 & 1860 & 1860 & 100.00 \\
\hline 16. & Sitapur & 25 & 25 & 100.00 & 7397 & 7397 & 100.00 & 2307 & 2307 & 100.00 \\
\hline 17. & Lakhimpur Kheri & 20 & 20 & 100.00 & 8355 & 8355 & 100.00 & 1930 & 1930 & 100.00 \\
\hline 18. & Hardoi & 5 & 5 & 100.00 & 8478 & 8478 & 100.00 & 1978 & 1978 & 100.00 \\
\hline 19. & Kanpur Dehat & 60 & 60 & 100.00 & 3536 & 3536 & 100.00 & 1149 & 1149 & 100.00 \\
\hline 20. & Saharanpur & 25 & 25 & 100.00 & 3766 & 3766 & 100.00 & 1720 & 1720 & 100.00 \\
\hline & Total & 794 & 777 & 97.86 & 93542 & 93542 & 100.00 & 35294 & 35294 & 100.00 \\
\hline
\end{tabular}

Proper sanitation, avoidance of open-air defecation and safe drinking water supply are being ensured from other departments' support and the aetiology of $60 \%$ AES is undetermined, which will be worked out in forthcoming time. 


\section{Acknowledgements}

The authors are thankful to all officers particularly Sri Rahul Dey, Technical Official E. Branch, Directorate of Health Services, Govt of UP who have helped directly or indirectly in bringing out the document in the present form. Thanks are also due to the Director, Directorate of NVBDCP for their kind support and encouragement.

\section{Conflict of Interest: None}

\section{References}

1. Bhardwaj M, Suri JC, Narain B, Arora RR, Lal P. Serological study of JE in Deoria district of Uttar Pradesh. J Commun Dis. 1981 Jun;13:96-101. [PubMed] [Google Scholar]

2. Bandyopadhyay B, Bhattacharyya I, Adhikary S, Mondal S, Konar J, Dawar N, Biswas A, Bhattacharya N. Incidence of Japanese Encephalitis among Acute Encephalitis Syndrome Cases in West Bengal, India. Biomed Res Int. 2013;2013:896749. [PubMed] [Google Scholar]

3. Chakraborty D, Banerjee S, Maji D, Dey KT, Mondal P, Basu M. A descriptive study of Japanese Encephalitis in West Bengal, India, based on surveillance data: changing pattern observed in recent years. Sch J App Med Sci. 2015;3(1E):320-8. [Google Scholar]

4. Chakrabarty S, Saxena VK, Bhardwaj M. Epidemiological investigation of Japanese Encephalitis outbreak in Gorakhpur and Deoria districts of Uttar Pradesh 1985. J Commun Dis. 1986;18(2):103-8. [PubMed] [Google Scholar]

5. Gulati BR, Singha $H$, Singh BK, Virmani N, Khurana SK, Singh RK. Sero-surveillance for Japanese Encephalitis virus infection among equines in India. J Vet Sci. 2011 Dec;12(4):341-5. [Google Scholar]

6. Kanojia PC, Shetty PS, Geevarghese G. A long-term study on vector abundance \& seasonal prevalence in relation to the occurrence of Japanese Encephalitis in Gorakhpur district, Uttar Pradesh. Indian J Med Res. 2003 Mar;117:104-10. [PubMed] [Google Scholar]

7. Japanese Encephalitis. Directorate General of Medical \& Health Services, UP and Regional Office of Health \& Family Welfare (Government of India), Lucknow, 2005. p.48.

8. Kar NJ, Bora D, Sharma RC, Bhattacharjee J, Datta KK, Sharma RS. Epidemiological profile of Japanese Encephalitis in Gorakhpur district, Uttar Pradesh, 19821988. J Commun Dis. 1992;24(3):145-9. [PubMed] [Google Scholar]

9. Khare JB. Current status of Japanese Encephalitis in Uttar Pradesh: Proceedings of the National Conference on Japanese Encephalitis. New Delhi: ICMR; 1982, p. 22-4.

10. Kumar R, Mathur A, Kumar A, Sharma S, Saksena PN, Chaturvedi UC. Japanese Encephalitis an important cause of acute childhood encephalopathy in Lucknow,
India. Postgraduate Med J. 1988 Jan;64:18-22. [PubMed] [Google Scholar]

11. Kumari R, Joshi PL. A review of Japanese Encephalitis in Uttar Pradesh, India. WHO South-East Asia J Public Health. 2012 Oct-Dec;1(4):374-95. [PubMed] [Google Scholar]

12. Mathur A, Chaturvedi UC, Tandon HO, Agarwal AK, Mathur GP, Nag D, Prasad A, Mittal VP. Japanese Encephalitis epidemic in Uttar Pradesh, India during 1978. Indian J Med Res. 1982 Feb; 75:161-9. [PubMed] [Google Scholar]

13. Narshimam MV, Rao CK, Bendle MS, Yadava RL, Johri YC, Pandey RS. Epidemiological investigation on Japanese Encephalitis outbreak in Uttar Pradesh during 1988. J Com Dis. 1988 Dec;20:263-75. [PubMed] [Google Scholar]

14. Roy AR, Tandon SK, Agarwal, Banerjee G. Seroprevalence of Japanese Encephalitis virus infection in Lucknow. Uttar Pradesh. Indian J Med Res. 2006 Aug;124:211-2. [PubMed] [Google Scholar]

15. Saxena V, Dhole TN. Preventive strategies for frequent outbreaks of Japanese Encephalitis in Northern India. J Biosci. 2008 Nov;33:505-14. [PubMed] [Google Scholar]

16. Srivastava VK, Sinha NK, Singh A, Chandra R. Japanese Encephalitis situation in Gorakhpur Division, UP. J Commun Dis. 2003 Mar;35(1):56-8. [PubMed] [Google Scholar] 